\title{
Effect of Chemical Fertilizers, Chicken Manure and Bacteria Inoculation Treatments on Productivity of Brassica Alba, L. Plants under North Sinai Conditions
}

\author{
Ali, M. A. M. \\ Plant Production Department Fac. of Environ. Agric. Sci., El-Arish. Suez Canal Univ; Egypt.
}

Received: $13 / 12 / 2013$

\begin{abstract}
A field experiment was carried out during winter seasons of 2008/2009 and 2009/2010 at the experimental farm of ornamental and medicinal plants, Faculty of Environmental Agriculture Sciences at El-Arish, Suez Canal University, North Sinai, to study the effect of different types of fertilizers; i.e., chemical fertilizer (NPK), chicken manure (ChM) and three types of inoculation bacteria phosphate solving bacteria (PSB), nitrogen fixing bacteria (NFB) and potassium release bacteria (KRB) on growth, seed and fixed oil yields of White Mustard (Brassica alba, L.) plants. Results showed that application of ChM $20 \mathrm{~m}^{3} /$ fed. (full dose) alone, ChM $10 \mathrm{~m}^{3} /$ fed. (half dose) $+\mathrm{NFB}$ or ChM (half dose) + PSB enhanced most Brassica alba, L. plants growth characteristics in both seasons as compared to chemical fertilizer in both seasons. As well as; application of ChM (half dose) with PSB increased all plant growth parameters, viz; fresh and dry weights of roots, leaves, shoots and total fresh weights as well as branches number per plant. The highest leaf pigments content, NPK and carbohydrates percentages were recorded with ChM (half dose) + PSB. Also, application of ChM + PSB gave highest seed yield. The favorable treatments for producing the highest of fixed oil yield/fed was ChM (half dose) + PSB or plus NFB. Application of ChM (half dose) with inoculation of PSB was the favorable treatment for increasing total seed yield and its components and fixed oil yields expressed as number and weight of seeds per plant and per fed. in both season followed by the treatment received ChM (half dose) + NFB only.
\end{abstract}

Keywords: Brassica alba, chemical fertilizer, inoculation bacteria, chicken manure.

\section{INTRODUCTION}

White Mustard (Brassica alba, L.) plant belongs to Family Brassicaceae, native to Mediterranean region and the Crimea, but introduced into other a country. It has become naturalized in many areas and is a weed of cultivated lands. Is among the Medicinal plants that can be cultivated in the new land. White Mustard seeds contains an enzyme myrosin and a glucoside sinalbin which yields upon hydrolysis, acrinyl isothiocyanate, a pungent tasting but almost odorless oil. Sinalbin mustard oil is only slightly volatile with steam, and causes blisters on the skin.

The medicinal uses of Brassica alba, L. is a good effect on rheumatic and used as flavoring material in food also use in salad and in industry food of sauces mustard. For all these uses of this plant is considered one of the most valuable medicinal plants, which needs research dealing with organic and biological agriculture for product pure drug, free from the chemical materials percentages, which are harmful on the public health.

Also we need of increasing the medicinal plant production in Egypt, it must be an ultimate goal to meet the great increase of population to avoid chemical therapy side effect on human health through utilization of the medical herbs, also to increase the economic revenue and foreign currency through their production over that the world began to recently come back to nature in particular for utilizing medical plants and use microorganisms in biofertilization to reduce or replace the chemical fertilizer.

To confront this problem, it was necessary to develop alternative methods of supplying nutrients to growing plant the utilization of biofertilizer is considered today by many scientists as a promising alternative particularly for developing countries.

The significant role of chemical fertilizers in increasing the medicinal plants production is fully recognized. However, in the recent years, many constraints have been raised due to their adverse impacts on the public health, environment and national income. Biofertilizers are, generally, based on altering the rhizospher flora, by seed or soil inoculation with certain organisms, capable of inducing beneficial effect on a compatible host. Biofertilizers mainly comprise nitrogen fixer, phosphate dissolvers or potassium release bacteria. These organisms may affect their host plant by one or more mechanisms such as nitrogen fixation, production of growth promoting substance or organic acids, enhancing nutrients uptake or protection against pathogens.

Therefore, this investigation aimed to study the effect of chemical fertilizer, chicken manure and biofertilization with nitrogen fixing bacteria, phosphorus solving bacteria, potassium release bacteria on the growth, yield and the main components of mustard plant to reveal the suitable treatments producing the highest herbs containing more fixed oil. El-sawy et al., (1998) on Ammi visnaga, Saleh et al.,(1998) on datura, Harridy and Amara (1998) on roselle plant and Kandeel et al, (2002) on sweet basil, Nour EL-Dein(2004) on Brassica alba, L. and in other plants and Abdel-Ghani (2008), Abd-Allah et al., (2001) and Hashem et al., (2013) on rosemary found that inoculation with full dose of in-organic $\mathrm{N}$ - fertilizer remarkably increase growth and yield . 


\section{MATERIALS AND METHODS}

The main objective of this research was to study the effect of different types of fertilizers; i.e., chemical fertilizer (NPK), organic manure source as chicken manure (ChM), and three types of inoculation bacteria or three bio-fertilizers phosphate solving bacteria (PSB), potassium release bacteria $(\mathrm{KRB})$ and nitrogen fixing bacteria (NFB) on growth and yield of Brassica alba, L. plants. Plants were grown in the winter season in sandy soil by using drip-irrigation system. The mechanical and chemical analyses of the soil used and organic manure were tabulated in (Tables $1 \& 2$ ) and irrigation water used analyses in (Table 3). The source of chicken manure $(\mathrm{ChM})$ was from poultry farm at North Sinai. Meteorological data (temperature degrees $\left(c^{\circ}\right)$, relative humidity (\%) and total rain (mm. /month) for El-Arish region during $(2008 / 2009 \& 2009 / 2010)$ seasons is shown in (Table 4).

The seeds of White Mustard (Brassica alba, L.) were obtained from Medicinal and Aromatic Plants Section, El-Dokki, Agricultural Research Center Cairo Egypt. The seeds were sown on $15^{\text {th }}$ November in 2008 and 2009 seasons, respectively directly in experimental land. The distance between rows was $75 \mathrm{~cm}$ and between hills in the same line was $25 \mathrm{~cm}$. plot area was $10.80 \mathrm{~m}^{2}$. $(6$ $\mathrm{m}$. long and $1.80 \mathrm{~cm}$ wide). After germination the plants were thinned at two plants per hill then after one week thinned at one plant per hill (21333 plants/fed.).

The plants of Brassica alba, L. were harvested at end March in both seasons when the pods turns golden green and the seeds were firm enough.

Thre strains of microorganism were used in this study; the first was nitrogen fixing bacteria (NFB) (Azospirrlum brasilense,), phosphorus solving bacteria (PSB) (Paenibacillus polmyx) and potassium release bacteria (KRB) (Pseudomonas fluerescens,). The source of NFB, PSB and KRB was obtained from the Bio Agriculture Research Center, The inoculated $(500 \mathrm{ml} / \mathrm{l})$ was diluted three times (after 20 days from appearance of the real leaves then every 15 days between another doses) $100 \mathrm{ml} /$ plant every season and dipped on root zone of the White Mustard (Brassica alba, L. plants). The bacteria were preserved on specific media under (1$8^{\circ} \mathrm{C}$ ) to use it in different addition stages.

This study included 11 treatments as follows:

1- Full dose of chemical fertilizer as [150 kg of ammonium sulphate $(20.5 \% \mathrm{~N}) ; 150 \mathrm{~kg}$ of calcium super phosphate $\left(16 \% \mathrm{P}_{2} \mathrm{O}_{5}\right)$ and $75 \mathrm{~kg}$ of potassium sulphate $\left.\left(48 \% \mathrm{~K}_{2} \mathrm{O}\right)\right] /$ fed, (NPK).

2- Half dose of (NPK) as [75 kg of ammonium sulphate $+75 \mathrm{~kg}$ super phosphate $+35.5 \mathrm{~kg}$ of potassium sulphate]/fed + bacteria inoculation of nitrogen fixing bacteria (NFB).

3- Half dose of (NPK) + phosphate solving bacteria (PSB).

4- Half dose of (NPK) + potassium release bacteria (KRB).

5- Half dose of (NPK) + NFB +PSB + KRB.

6- Full dose of chicken manure $\left(20 \mathrm{~m}^{3} / \mathrm{fed}\right)(\mathrm{ChM})$.

7- Half dose of $(\mathrm{ChM}) 10 \mathrm{~m}^{3} / \mathrm{fed}+\mathrm{NFB}$.

8- Half dose of (ChM) + PSB.

9- Half dose of $(\mathrm{ChM})+\mathrm{KRB}$.

10- Half dose of $(\mathrm{ChM})+\mathrm{NFB}+\mathrm{PSB}+\mathrm{KRB}$.

11-Half dose of (ChM) + half dose of (NPK).

The plots which included fertilization with calcium super phosphate and chicken manure treatments was added before planting in each season in only one dose. As for nitrogen and potassium fertilizers they were divided into in five equal doses alternately with bacteria inoculation treatments.

Table (1): Some initial chemical and physical characteristics of soil.

\begin{tabular}{|c|c|c|}
\hline Parameters & $2008 / 2009$ & $2009 / 2010$ \\
\hline \multicolumn{3}{|c|}{ Dissolving ions meq.L-1 (soil past extract) } \\
\hline $\mathrm{Ca}^{++}$ & 3.03 & 2.10 \\
\hline $\mathrm{Mg}^{++}$ & 2.11 & 2.20 \\
\hline $\mathrm{Na}^{+}$ & 1.18 & 4.49 \\
\hline $\mathbf{K}^{+}$ & 0.48 & 0.31 \\
\hline $\mathrm{Cl}^{-}$ & 1.02 & 2.30 \\
\hline $\mathrm{CO}_{3}^{--}$ & 0.00 & 0.00 \\
\hline $\mathrm{HCO}_{3}^{-}$ & 2.00 & 2.40 \\
\hline $\mathrm{SO}_{4}^{--}$ & 3.78 & 4.40 \\
\hline ECe (dsm-1) & 0.68 & 0.91 \\
\hline pH (1: 2.5) & 8.10 & 8.20 \\
\hline Organic carbon (g./kg $\left.{ }^{-1}\right)$ & 0.93 & 1.22 \\
\hline Organic matter $\left(\mathrm{g} . / \mathrm{kg}^{-1}\right)$ & 1.60 & 2.10 \\
\hline $\mathrm{Ca} \mathrm{CO}_{3}\left(\mathrm{~g} . / \mathrm{kg}^{-1}\right)$ & 3.95 & 3.95 \\
\hline \multicolumn{3}{|l|}{ Particular size distribution \% } \\
\hline Clay & 0.16 & 0.16 \\
\hline Silt & 0.33 & 0.33 \\
\hline Fine sand & 76.1 & 76.1 \\
\hline Coarse sand & 18.71 & 18.71 \\
\hline Soil texture & Sandy soil & Sandy soil \\
\hline
\end{tabular}


Table (2): Chemical analyses of chicken manure in the two seasons.

\begin{tabular}{|c|c|}
\hline $\begin{array}{r}\text { Parameters } \\
\end{array}$ & Chicken manure(ChM) \\
\hline T. nitrogen g. $\mathrm{kg}^{-1}$ & 33.5 \\
\hline T. phosphor g.kg-1 & 0.40 \\
\hline T. potassium g.kg ${ }^{-1}$ & 21.0 \\
\hline Organic carbon g.kg-1 & 431 \\
\hline Organic matter g.kg & 743 \\
\hline C/N Ratio & 12.9 \\
\hline
\end{tabular}

Table (3): Chemical analyses of irrigation water.

\begin{tabular}{|c|c|c|c|c|c|c|c|c|c|c|c|}
\hline \multirow{3}{*}{ pH } & \multirow{3}{*}{$\begin{array}{c}\mathrm{EC} \\
\left(\mathrm{dSm}^{-1}\right)\end{array}$} & \multicolumn{8}{|c|}{ Soluble ions (meq/L) } & \multirow{3}{*}{ S.A.R } & \multirow{3}{*}{$\begin{array}{c}\text { S.S.P } \\
\%\end{array}$} \\
\hline & & \multicolumn{4}{|c|}{ Cations } & \multicolumn{4}{|c|}{ Anions } & & \\
\hline & & $\mathrm{Ca}^{++}$ & $\mathbf{M g}^{++}$ & $\mathrm{Na}^{+}$ & $\mathbf{K}^{+}$ & $\mathrm{Cl}^{-}$ & $\mathrm{HCO}_{3}{ }^{-}$ & $\mathrm{CO}_{3}^{--}$ & $\mathrm{SO}_{4}^{--}$ & & \\
\hline 7.5 & 7.54 & 15.4 & 14.6 & 45.2 & 0.2 & 47.5 & 2 & - & 25.9 & 11.6 & 60 \\
\hline
\end{tabular}

Table (4): Meteorological data: temperature degrees $\left({ }^{\circ} \mathrm{C}\right)$, relative humidity $(\%)$ and total rain (mm./month) for ElArish region during (2008/2009 \& 2009/2010) seasons.

\begin{tabular}{|c|c|c|c|c|c|c|c|c|c|c|}
\hline \multirow{3}{*}{ Months } & \multicolumn{5}{|c|}{$2008 / 2009$} & \multicolumn{5}{|c|}{$2009 / 2010$} \\
\hline & \multicolumn{3}{|c|}{ Temperature $\left({ }^{\circ} \mathrm{C}\right)$} & \multirow{2}{*}{$\begin{array}{l}\text { R.H } \\
(\%)\end{array}$} & \multirow{2}{*}{$\begin{array}{c}\text { Rain } \\
\text { (mm/month) }\end{array}$} & \multicolumn{3}{|c|}{ Temperature $\left({ }^{\circ} \mathrm{C}\right)$} & \multirow{2}{*}{$\begin{array}{l}\text { R.H } \\
(\%)\end{array}$} & \multirow{2}{*}{$\begin{array}{c}\text { Rain } \\
\text { (mm/month) }\end{array}$} \\
\hline & Max. & Min. & Avr. & & & Max. & Min. & Avr. & & \\
\hline November & 25.3 & 14.4 & 19.7 & 71 & 16.2 & 25.0 & 12.0 & 12.5 & 70 & 17.0 \\
\hline December & 21.4 & 10.2 & 15.5 & 66 & 22.2 & 20.0 & 9.0 & 14.5 & 69 & 28.0 \\
\hline January & 19.0 & 8.0 & 13.5 & 73 & 28.0 & 20.2 & 9.3 & 15.0 & 70 & 15.0 \\
\hline February & 19.0 & 8.0 & 13.5 & 70 & 19.0 & 20.4 & 8.3 & 14.5 & 67 & 11.0 \\
\hline March & 21.0 & 9.0 & 15.0 & 70 & 15.0 & 20.6 & 9.3 & 14.9 & 72 & 23.9 \\
\hline April & 25.0 & 12.0 & 18.5 & 67 & 11.0 & 26.9 & 10.2 & 18.5 & 71 & - \\
\hline
\end{tabular}

*Meteorological Laboratory at EL-Arish - North Sinai.

Samples of three plants were randomly taken from each plot to determine the following parameters and statistically analyzed:

\section{Vegetative growth parameters:}

- Plant height $(\mathrm{cm})$, main stem diameter $(\mathrm{mm})$, number of leaves, branches/plant, root length $(\mathrm{cm})$ and number of root branches.

-Fresh and dry weights/plant $(\mathrm{g})$ of leaves, stem, roots and total herb, length of roots $(\mathrm{cm})$.

Vegetative growth parameters were recorded at full flowering stage period.

All plant parts were dried at $70{ }^{0} \mathrm{C}$ till constant weight, then dry weight of root, leaves and stem were recorded and total dry weight of plant were calculated.

Yield and its components parameters:

Number, fresh and dry weights of pods/plant (g), dry weight of 100 pods and dry weight of 100 seeds $(\mathrm{g})$.

Chemical analysis:

1- Photosynthetic pigments were extracted and determined in fresh leaves samples (as $\mathrm{mg} / \mathrm{gm}$ ) by pure acetone according to the procedure of Fadeel (1962).

2-Nitrogen, phosphorus, potassium and total carbohydrates percentages were determined in dried harvested leaves of White Mustard plants at $70^{\circ} \mathrm{C}$ for 72 hours according to A.O.A.C. (1980) .

Determination of fixed oil percentage and yield per plant:

Soxhlet method was used for estimation of fixed oil percentage in dry seeds per plant $(\mathrm{ml})$ as stated by the A.O.A.C. (1980). Oil yield per plant (ml) and per fed. (L) were calculated as follows:
Oil yield per plant $(\mathrm{ml})$

$=\frac{\text { Fixed oil percentage } \mathrm{x} \text { Seeds dry weight } / \text { plant }(\mathrm{g})}{100}$

\section{Statistical analysis:}

The experimental design was complete randomized block design with three replication and statistical analysis of the obtained data was carried out according to Snedecor and Cochran (1980). Duncan's multiple range tests was used for comparison among means (Duncan, 1958).

\section{RESULTS AND DISCUSTION}

Effect of chemical fertilizer, chicken manure and bacteria inoculation treatments on the morphological characters of White Mustard Brassica alba, L plant.

Data presented in Table (5) show that chicken manure treatments generally increased White Mustard (Brassica alba, L.) plant height, number of leaves, branches/plant, induced significant effect for stem diameter, root length and number of root branches parameters show significant effects compared with those of chemical fertilization ones alone or chicken manure $20 \mathrm{~m}^{3} / \mathrm{fed}$. alone or with other bacteria inoculation. The treatments by $10 \mathrm{~m}^{3} / \mathrm{fed}$. chicken manure with bacteria inoculation (PSB) gave highly significant increase and were more effective in increasing all morphological characters in this respect. These results hold true in the two seasons. These results are in accordance with those found by Chezhiyan et al. (2003) on Phyllanthus amarus, Sakr (2005) on senna plants. Abdel-Kader and Ghaly (2003) showed that 
treating coriander plant with biofertilizer (Nitrobien) increased the plant height and number of shoots per plant. Sharaf (1995) on Datura stramonium,L. showed that, growth parameters as rate of branching number and plant height was positively influenced by free living fixating bacteria i.e. Azospirillum brasilense and Azotobacter. Also, Abdou (2003) on Chrysanthemum morifolium, L. plants stated that, all studied vegetative growth characters were significantly increased due to the application of (PSB) biofertilization. Abou-Aly and Gomaa (2002) showed that inoculation with Azotobacter chroococcum or Azospirillum brasilense combined with Glomus mosseae gave a significant increase in vegetative growth of coriander plants. Also these results are similar to those found by Abd-Allah et al., (2001) and Hashem et al., (2013) on rosemary found that all growth characters herb significantly increased with all bio-fertilization treatements.

The increase in leaves number/plant due to organic fertilization treatments might be due to their role in bud differentiation as well as branching, leading to more leaves. Moreover, the enhancing effect in this respect might be due to the positive effect of it on branching as mentioned before.

This result may be attributed to the increments of extractable phosphorus of sandy and calcareous soil which enhance root growth and consequently the vegetative growth.

The increase in plant height resulting from using chicken manure might be due to that it might enhance cell division and/or cell enlargement. These nutrients might participate directly or indirectly on plant anabolism resulting in more plant materials.

However, the increase in plant height might be due to the application of chicken manure fertilization for its importance to consist the amino acids to form the proteins, which participate in cell enlargement and cell division. While phosphorus has an important role in producing energy for the physiological processes as synthesis proteins by formation the coenzyme adenine triphosphate (ATP).

Effect of chemical fertilizer, chicken manure and bacteria inoculation treatments on the fresh and dry weights of vegetative growth on Brassica alba, $L$ plant.

The data presented in Table 6 show that herb fresh and dry weights per plant gradually increased by using the treatments of $10 \mathrm{~m}^{3} / \mathrm{fed}$. chicken manure plus bacteria inoculation phosphate solving bacteria. Moreover, addition these treatment gave the highest values of fresh and dry weights of total plant (881.6 g. 971.4g.) and (132.5g. - 115.2g.) in the first and second seasons, repectively and showed significant increase compared to the other treatements under study. These results were similar to those found by Abd- Allah et al. (2001) mentioned that application of biofertilizers (Biogene and Nitrobien) improved vegetative growth of egg plants and increases the fresh and dry weights per plant, Abd EL-Latif et al. (2002) obtained the maximum values of plant height, number of branches/plant, fresh and dry weights of Matricaria chamomill, L. plants when received biofertilizer treatment of $4 \mathrm{~kg}$ Biogene / faddan. Also, Shalan (2004) on borage plants using biofertilizers application plus organic manure, Sakr (2005) on senna plants using organic-inorganic and biofertilizers they found that al organic and biofertilizers treatements increased plant growth under study .

Effect of chemical fertilizer, chicken manure and bacteria inoculation treatments on the seed yield components on Brassica alba, L plant:

In table (7) data show that average between the treatments it is clear in both seasons. It can be concluded that $\mathrm{ChM}$ at the half dose supplemented with PSB increased the seed yield components during both seasons. Data also reveal that there were significant differences among treatments in the two seasons. Also, the superior treatment which increased yield and its component; viz, number of pods per plant (703.6 $\mathrm{g}-$ $723.6 \mathrm{~g})$, dry weight of 100 seeds was $(0.5997 \mathrm{~g}-0.6967$ $\mathrm{g})$, weight of 100 pods was $(16.30 \mathrm{~g}-16.60 \mathrm{~g})$, fresh and dry weights of pods per plant. $(1146.8 \mathrm{~g}-1179.4 \mathrm{~g}$ and $820.5 \mathrm{~g}-967.5 \mathrm{~g} /$ plant in the first and second seasons respectively) that application of ChM $10 \mathrm{~m}^{3} / \mathrm{fed}$. with PSB was the superior interaction treatment, which significantly increased all yield parameters. In the other hand, seeds dry weight per plant (g) and per fed.(kg) recorded highly significant increase by using the same treatment compared to the other treatments

These results are in accordance with those reported by Yadav and Khurana (2000) on fennel reported who that seed treatment with azotobacter improved number of umbels / plant, seeds / umbel and total seed yield.

The increments of total yield and its components due to application of ChM + PSB may be owe to a balanced $\mathrm{C} / \mathrm{N}$ ratio in plants which had moderately growth, and consequently good fruit set leading to an increase in number and weight of fruits per plant. On the other hand, the reduction in total yield via application of PSB may be owe directly to the inhibition effect on plant growth as shown in Table (7) and reduction in number and weight of seed per plant. These results are in agreements with those reported by Baboo and Rana (1995) on coriander, Singh (1998) on coriander and Garg et al., (2004) on fennel they reported that using bacteria inoculated by Azotobacter improved number of umbels/plant, seeds/umbel and total seed yield..

The increments of total yield due to $\mathrm{ChM}+\mathrm{PSB}$ application may be owe to the increments in, plant growth expressed as fresh weight of roots, leaves, stem and total fresh weight per plant; and dry weight per plant. In this respect, Attia and Saad (2001) on Catharanthus roseus,L. plants, Badr El-Din et al., (2001) on Trigonella foenum-greacum, L. and Harridy et al., (2001) on lemongrass plants mentioned that the highest total yield of fresh and dry herb were obtained by the plants inoculated with Azotobacter without NPK fertilizers. Zayed et al., (2004) on borage plants (Borago officinalis, L.) showed that treating plants with Nitrobein increased the yield especially at the rate of $600 \mathrm{gm} / \mathrm{kg}$ seeds compared with the other treatments. 
Effect of chemical fertilizer, chicken manure and bacteria inoculation treatments on the chemical constituents of Brassica alba, L plant.

The data of nitrogen, protein, phosphorus, potassium and total carbohydrates percentages in dried leaves of plants were shown in Table (8). The results clearly demonstrated that, $\mathrm{ChM}$ at the half dose plus phosphate solving bacteria caused a slight increase in the percentage of chemical constituents in the leaves during both season. However, the differences between inoculation treatments and control were a high significant in the first and the second season. These findings are in agreement with those obtained by Ali (2002) on Corianrum sativum, L. plants, and Helmy (2003) on roselle. Apparently, it is well known that phosphate solubilizing bacteria might enhance the phosphorylation via increased available-P in soil hence improved phosphorus percentage in leaves. Also these results might be due to that, phosphorine raised the available phosphorus in the soil and the plant tissues. As it is known that phosphorus is a constituent of nucleic acids, phospholipids the coenzymes NAD and NADP and most important as a consistent of ATP, thereby, phosphorus could significantly altered plant carbohydrate contents .

Effect of chemical fertilizer, chicken manure and bacteria inoculation treatments on the fixed oil yield of Brassica alba, $L$ plant.

The fixed oil percentage in dry seeds as affected by chicken manure and biofertilization (PSB) are shown in Table (9) showed that organic manure as $\mathrm{ChM}$ at the half dose plus phosphate solving bacteria had a significant effect on fixed oil percentage in both seasons. In the second season gave the fixed oil percentage in dry seed (28.15\%) compared to (27.45) in the first season it gave highest It did not differ significantly for all treatments in both seasons. These results are in accordance with those reported by, Harridy et al. (2001) on lemongrass, Shalan et al.,(2001) on chamomile Khater et al., (1996) on
Hibiscus sabdariffa, L plant, Eid and EL-Ghawwas (2002) on marjoram, Abdel-Kader and Ghaly (2003) on coriander plant. Concerning oil yield/ plant and per fed., which showed the highest values of oil yield per fed. by $\mathrm{ChM}$ at the half dose supplemented with PSB in the first and second seasons.

Effect of chemical fertilizer, chicken manure and bacteria inoculation treatments on the plant pigments on Brassica alba, $L$ plant.

Data illustrated the effect of (PSB) biofertilizer on chlorophyll a, chlorophyll b and carotenoids in leaves were presented in Tables (10). It revealed that in both seasons, application of (PSB) caused a significant increase in chlorophyll $\mathrm{a}, \mathrm{b}$ and carotenoids of plant leaves if compared with other treatments in the two seasons. These findings may prove that the beneficial effect of inoculation with phosphate solving bacteria it was mainly increasing the release of phosphorus in the soil which is reflected in increasing phosphorus activity and the growth promoting substances produced by them. Also, the role of phosphorus in stimulated chlorophyll synthesis through encourages pyridoxal enzymes formation which plays an important role in $\alpha$-amino levulinic acid synthetase as a primary compound in chlorophyll synthesis. The obtained results are in harmony with those obtained by Ali (2002) on Corianrum sativum, L. plant.

This increase led to an increment in the number of chloroplasts in the leaf, inducing chlorophyll synthesis and an increase cytokinin content. Cytokinin is known to delay senescence of plant tissue through its effect on reducing the loss of chlorophyll. Similar results on leaf pigments were also reported by Abd EL-Fattah and Sorial (2000) on squash, Abdel-Mouty (2000) on cowpea and Abdou (2003) on Chrysanthemum morifolium, L.

The above mentioned results agreed with those obtained by Abou-Aly and Gomaa (2002) on Corianderum sativum, L. 


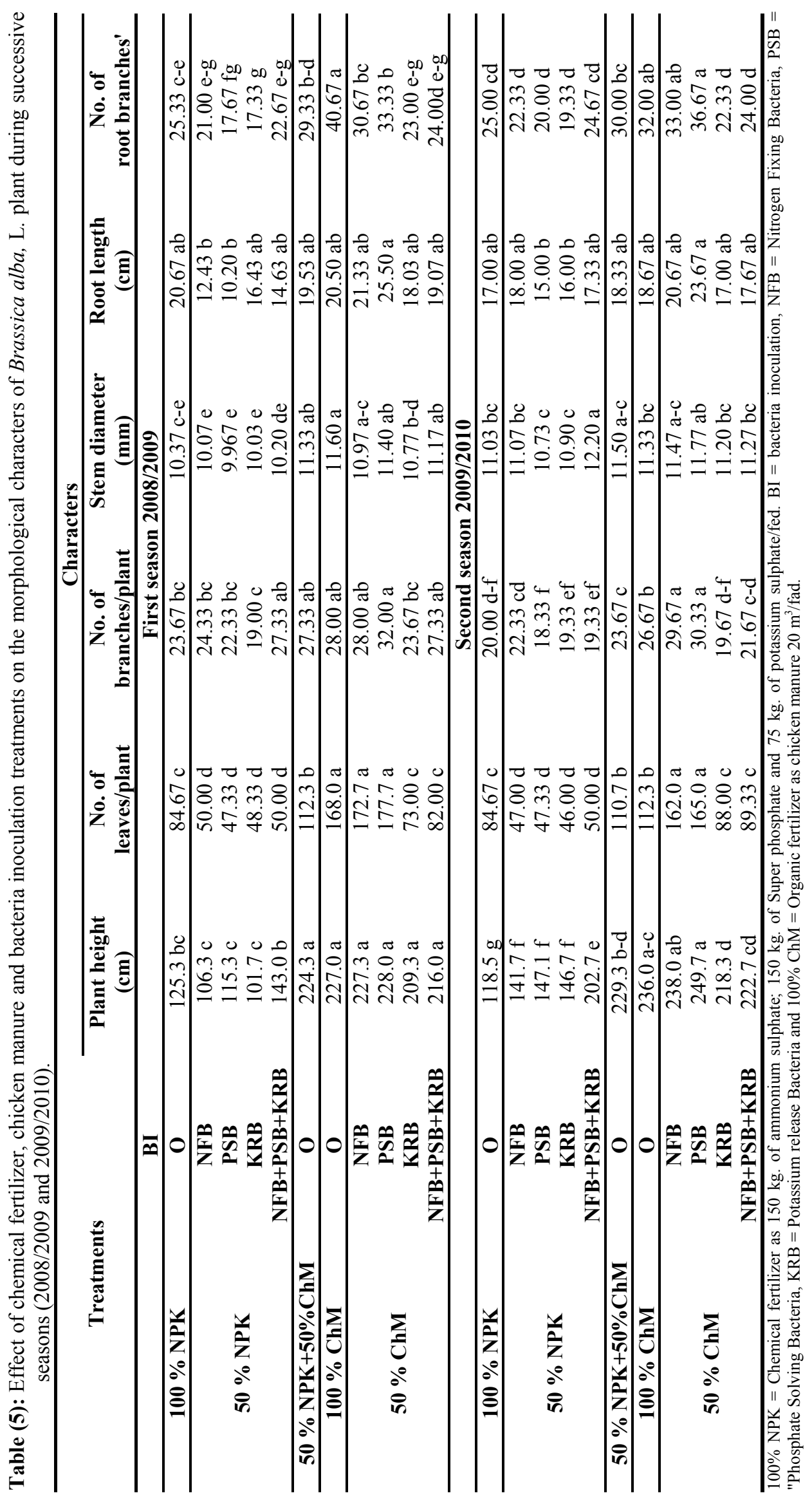




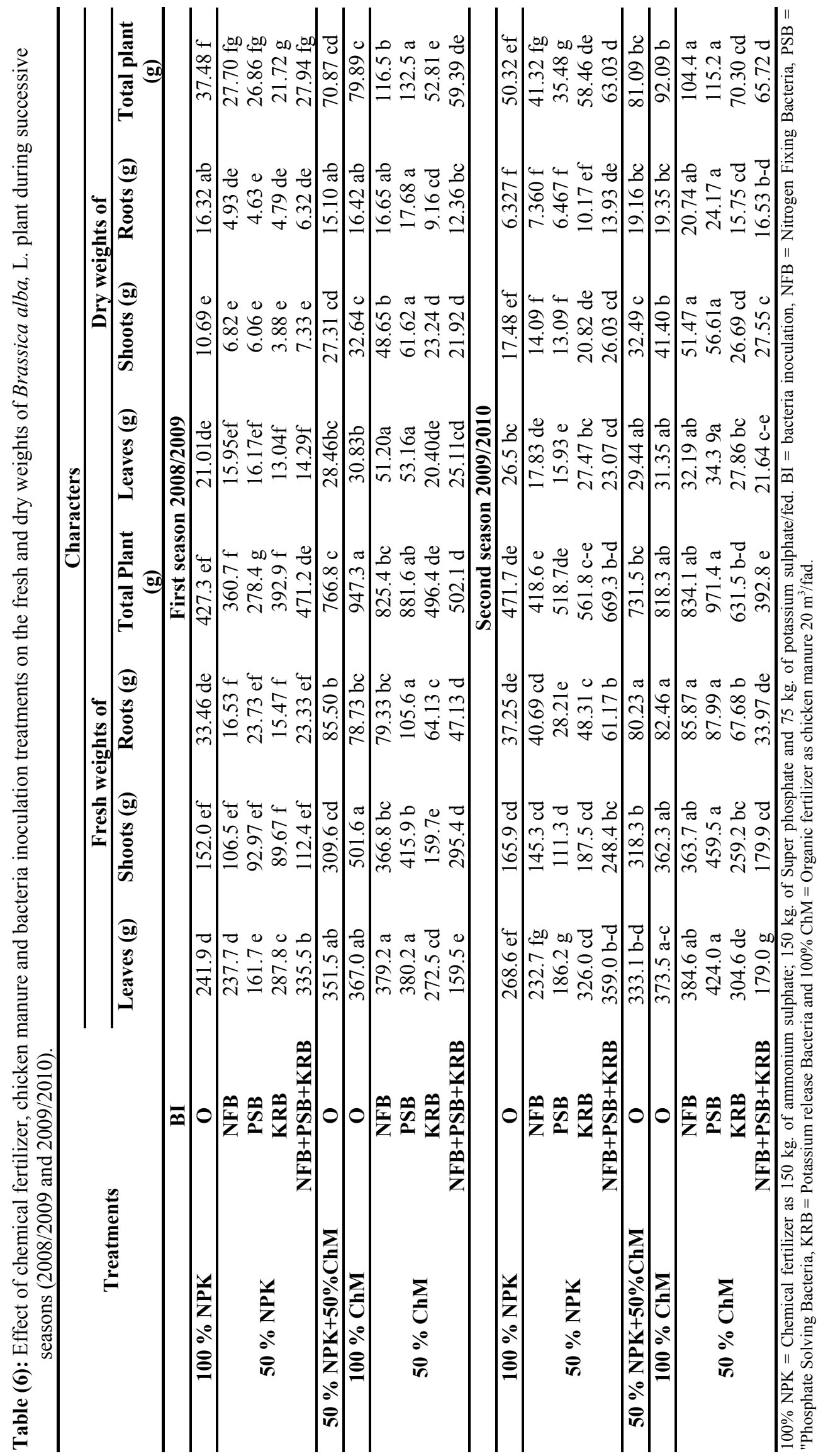




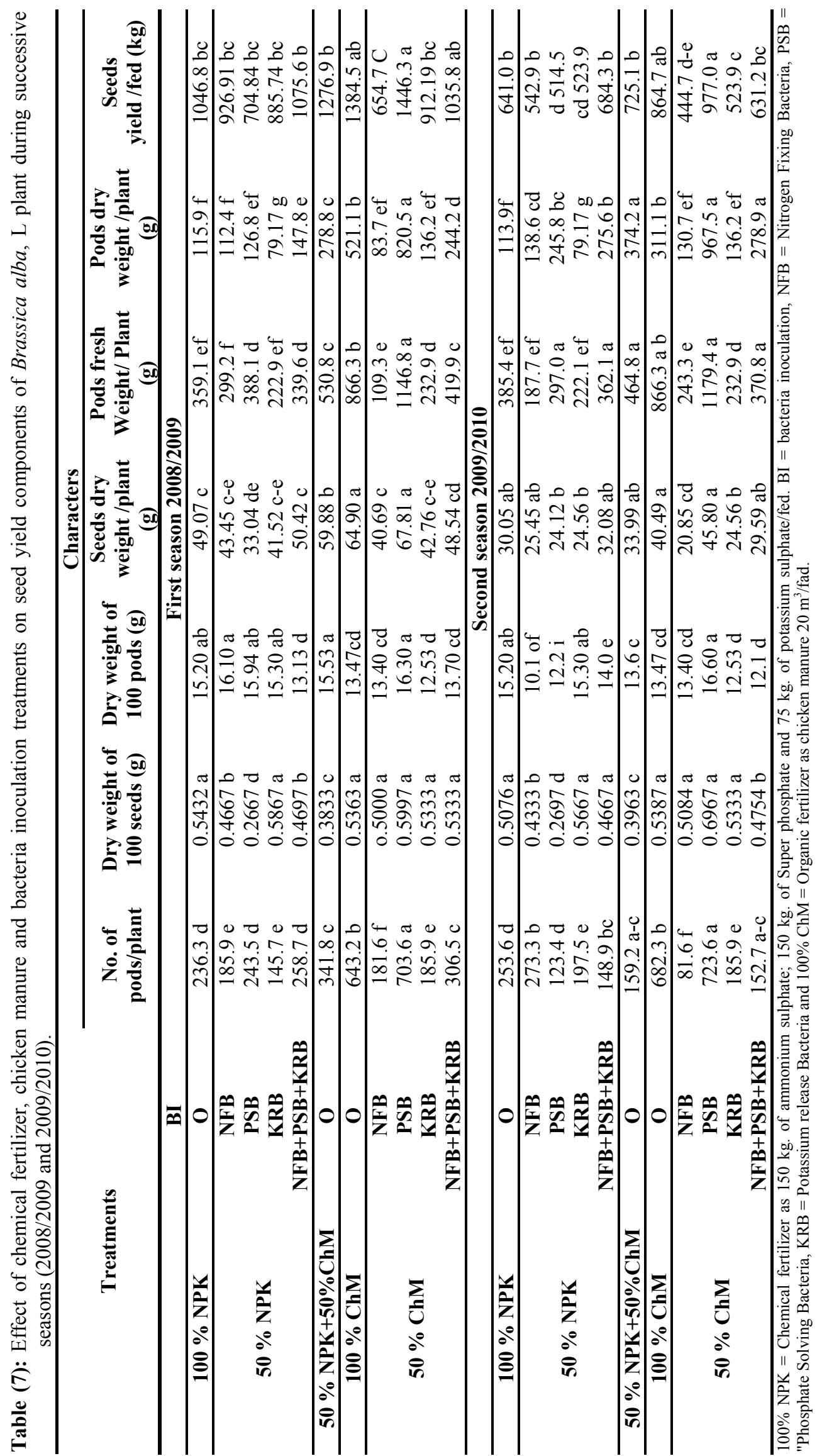




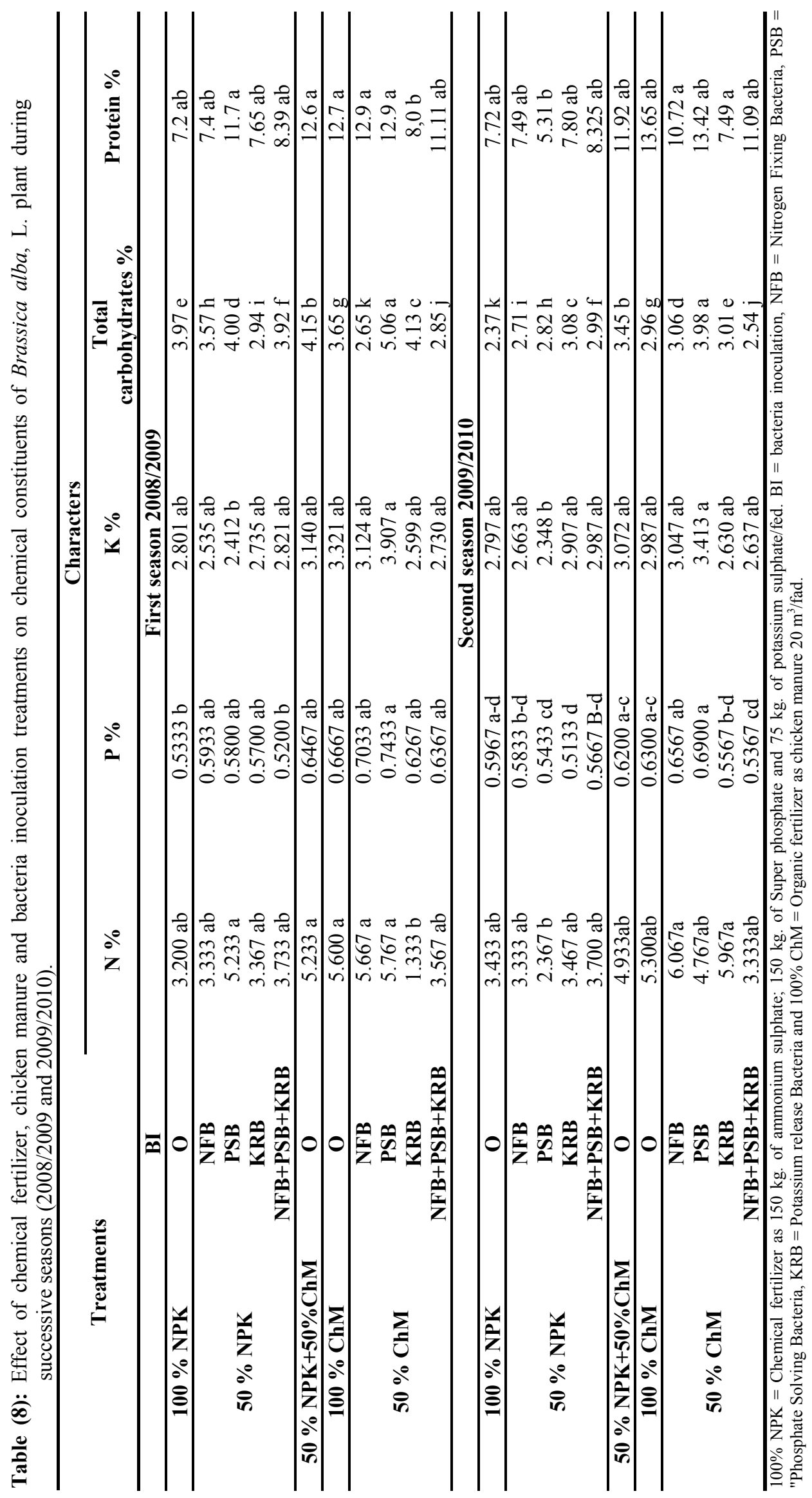




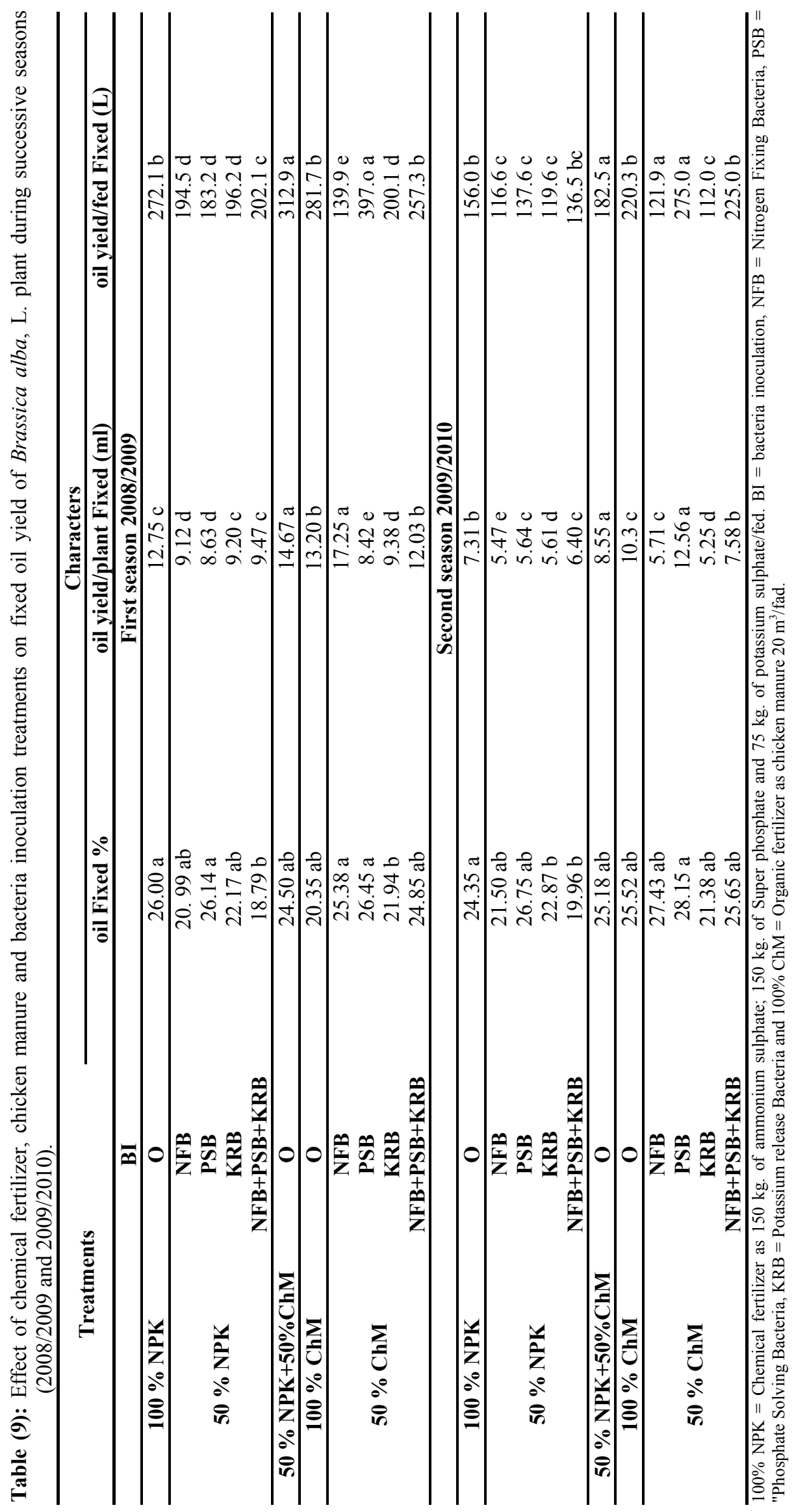




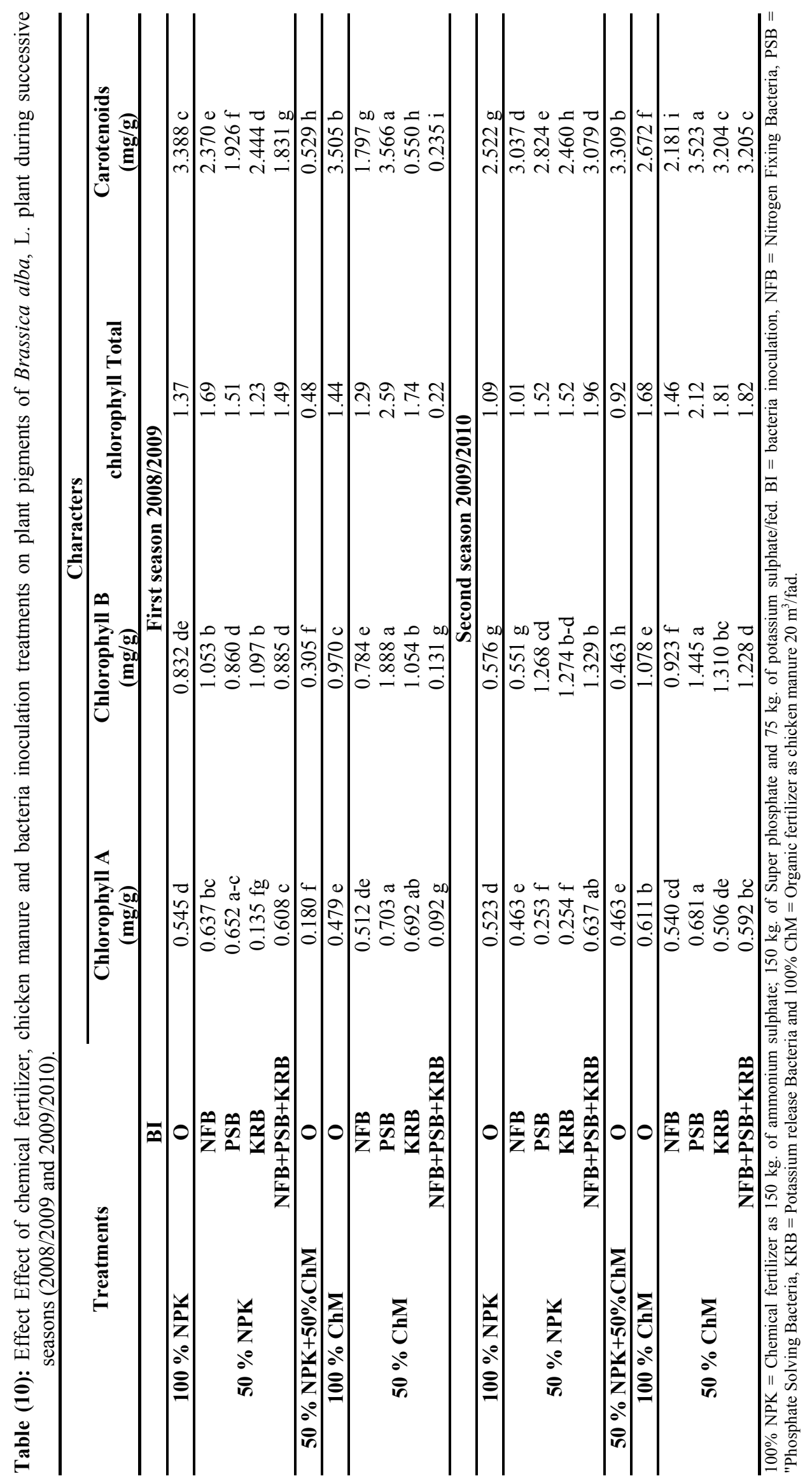




\section{REFERENCES}

A.O.A.C., (1980). Official Methods of Analysis. $12^{\text {th }}$ ed. Association of Official Analytical Chemists. Washington, D. C., USA.

Abd- Allah, E. M. M, I. M. Darwish and M. R. Mahmoud (2001). Influence of different source of nitrogen fertilizer on growth and yield of eggplant and some soil characteristic. J. Agric. Sci. Mansoura Univ., 28 (7): 5387-5403.

Abd EL-Fattah, M. A. and Mervat E. Sorial (2000). Sexexpression and productivity response of summer squash to biofertilizer application under different nitrogen levels. Zagazig J. Agric. Res. Vol. 27 No. (2): 255-281.

Abd EL-Latif, T. A., Amal G. Salem and N. G. Ghaly (2002). Effect of chemical and bio-nitrogen fertilizers on chamomile plants (Matricaria chamomilla, L.). J. Agric. Sci. Mansoura univ., 27 (3): 1757-1771.

Abdel-Mouty, M. M. (2000). Effect of chemical and bio-nitrogen fertilizer on the growth and yield of cowpea plant (Vigna sinesis Savi.) J. Agric. Sci. Mansoura Univ., 25 (7): 4437- 4450.

Abdel-Kader, H. and N. G. Ghaly (2003). Effects of cutting the herb and the use of Nitrobien and Phosphorine associated with mineral fertilizers on growth, fruit and oil yields, and chemical composition of the essential oil coriander plants (Corianrum sativum, L.) J. Agric. Sci. Mansoura Univ., 28 (3): 2161-2171.

Abdou, M. A. H. (2003). Growth and flowering of Chrysanthemum morifolium, L. plant. II. Effect of $\mathrm{N}$-mineral/N-biofertilizer and micronutrients on Chrysanthemum morifolium, Icecap. J. Agric. Sci. Mansoura Univ., 28 (6): 4931-4941.

Abou-Aly, H. E. and A. O. Gomaa (2002). Influence of dual inoculation with diazotrophs and phosphate solubilizers on growth, yield and volatile oil content of coriander plants (Coriandrum sativum, L.). Bull. Fac. Agric. Cairo Univ., 53(1): 93-113, Egypt.

Ali, M.S. (2002). Effect of organic and mineral fertilization and their combination on Coriandrum sativum, L. Minufia J. Agric. Res. Vol. 27 No. 5: 1263:1274.

Attia F. A. and O. A. O. Saad (2001). Biofertilizers as partial alternative of chemical fertilizer for Catharanthus roseus, G. Don. J. Agric. Sci. Mansoura Univ., 26 (11): 7193-7208.

Baboo, R. and N. S. Rana (1995). Effect of cutting management, nitrogenand phosphorus on growth and yield of coriander (Coriandrum sativum, L.) Indian J. of Agronomy, 40:2, 253- 255

Badr El-Din, S. M. S., Abdel-Aziz, R. A. and S. A. Abo-Sedera (2001). Effect of dual inoculation with Rhizobium - arbuscular mycorrhizal fungi on the production of legume-grass associations grown in Sinai soil. Egypt. J. of Microbiology, 36(3): 225-241.

Chezhiyan N., S. Saraswathy and R.Vasumathi (2003). Studies on organic manures, biofertilizeres and plant density on growth, yield and alkaloid content of (Phyllanthus amarus, Schum. and Thonn.). South Indian Horticulture., 51(1/6): 96 101.

Duncan D. B. (1958). Multiple ranges and multiple Ftest. Biometrics, 11: 1- 42 .

Eid, M. I. and E. O. El-Ghawwas (2002). Study on the responsibility of marjoram plants to biofertilizeres in sandy soil. Egypt. J. Appl. Sci., 17(3):163-175.

El-Sway M., E. A. Saleh, M. A. El-Borollosy, T. H. Nokhal, I. Fendrik and M. S. Sharaf (1998). Effectiveness of dual inoculation with diazotrophs and vesicular-arbuscular mycorrhizae on the growth and khellin content of Ammi visnaga,. Arab Universities J. of Agric. Sci., 6(2):357-371.

Fadeel A. A. (1962). Location and properties of chloroplasts and pigment determination in roots. Physiol Plants., 15: $130-147$.

Garg, V.K., P. K., Singh, R. S. Katiyar (2004). Yield, minerla composition and quality of coriander(Coriandrum sativum, L.) and fennel (Foeniculum vulgare, L.) grown in sodic soil. Indian J. of Agric. Sci. 74 (4):221-223.

Hashem, Hanan A.E. H., A.A. Meawad, G.A. Bisher and M.A. Elham (2013). Effect of Biofertilizer and Alternative Saline Water Irrigation on Rosemary Plants Under North Sinai Conditions. Zagazig J. of Agric. Res., Vol. 40 No.3 pag. 378398- 2013.

Harridy, I. M. A. and Mervat, A. T. Amara (1998). Effect of pre sowing inoculation of seeds by nitrogen fixed bacteria on growth, fruit production, sepals yield and chemical composition of roselle plants. Egyptian J. of Appl. Sci., 13(6): 217-231.

Harridy, I. M. A., S. G. I. Soliman and Mervat, A. T. Amara (2001). Physiological, chemical and biological studies on lemongrass Cymbopogan citrates, L. (D C) stapf in response to diazotrophic bacteria. J. Agric. Sci. Mansoura Univ., 26 (10): 6131- 6154.

Helmy, Laila M. (2003). Studies on the effect of irrigation intervals, bio and chemical fertilization on roselle plant productivity. J. Agric. Sci. Mansoura Univ., 28 (5): 3927-3945.

Kandeel, A. M., N. S. Abo-Taleb and A. A. Sadek (2002). Effect of biofertilizers on the growth, volatile oil yield and chemical composition of Ocimum basilicum, L. plant. Annals Agric. Sci., Ain Shams Univ. Cairo, 47(1):351-371.

Khater, M. R.; M. H. Abou Zied and A. A. Zayed (1996). Effect of irrigation intervals and number of plants per hill on growth and some metabolic production of roselle (Hibiscus sabdariffa, L.). Egypt J. Appl. Sci., 11(1):316-323.

Abdel-Ghani, Neama M. (2008). Physiological Studies on Rosemary and chamomile plants to study the effect of irrigation intervals growth, yield, oil production and chemical composition.

Nour EL-Dein, Y. and A. R. Souzan (2004). Resbonse of some medicinal plants to inoculationwith N2fixing and phosohate dissolving microorganisms 
on Brassica alba, L. and others plants. Minufly j. Agric. Res.Vol.30 No. (1):257-315

Sakr, W. R. (2005). Effect of organic and biofertilization on growth and constituents production of senna plants. Ph. D. Thesis, Fac. Agric., Cairo Univ., Egypt.

Saleh, E.A., M. EL-Sawy A. A. Refaat; M. K. AbdelFattah and M. S. Sharaf (1998). Effect of seed inoculation with some symbiotic N2-fixers on the growth of datura plant. Proc. $2^{\text {nd }}$ Conf. A. A. BNF, Cairo, Egypt, pp. 483- 497.

Singh, I. P. (1998). Effect of various doses of nitrogen and spacing on the yield of coriander (Coriandrum sativum, L).Bhartiya, Krishi, Anusandhan, Patrika, 1998, 13:3-4, 182-184

Salman, A. S. (2004). Effect of bio-fertilization on Ocimum basilicum, L. plant M. Sc. Thesis, Fac. Agric., Cairo Univ., Egypt.

Sharaf. A. E. M. (1995). Response of some medicinal plants to inoculation with symbiotic $\mathrm{N}_{2}$-fixers. Ph.D. Thesis Fac. Agric. Ain Shams Univ. Shalan, M. N.
(2004). Effect of compost and different sources of biofertilizeres, on borage plants (Borago officinalis, L.). Egypt. J. of Agric. Res., 83(1): 271-284

Shalan, M. N., E. O. El-Gawwas, M. M. Dessouky, and S. G. I. Soliman (2001). Effect of sources and levels of phosphorous fertilization on polish chamomile (Matricaria chamomilla, L.) J. Agric. Sci. Mansoura Univ., 26(4):2215-2233.

Snedecor, G. W. and W. G. Cochran, (1980). Statistical Methods. The Iowa State Univ. Press, Ames, Iowa, U.S.A.

Yadav, B. D. and S. C. Khurana, (2000). Effect of plant growth substances and Azotobacter on yield and yield attributing characters in fennel. Haryana Agric. Univ. J. of Res., 30(3-4):71-77.

Zayed, A. A. S. M. Selim, M. A. Hassanain, and Y. A. Hafez, (2004). Effect of sow spacing's, nitrogenous and bio-fertilization treatments on yield and chemical composition of borage plants (Borago officinalis, L.). Egypt. J. of Agric. Res., 82(2(Special Issue)): 187-206.

\section{تاثير معاملات التسميدالكيماوى وسبلة الدواجن والتلقيح البكتيرى على انتاجية نباتات الخردل الابيض تحت ظروف شمال سيناء البكاء

\author{
قسم الإنتاج النباتي كلية العلوم الزر محمد احمد محمود على . بيئيه ، العريش . جامعة قناة السويس ؛ مصر .
}

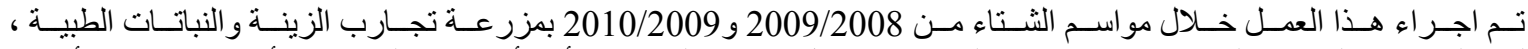

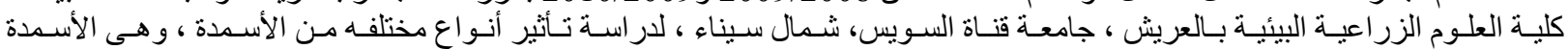

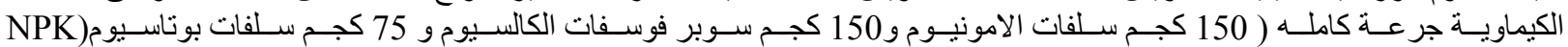

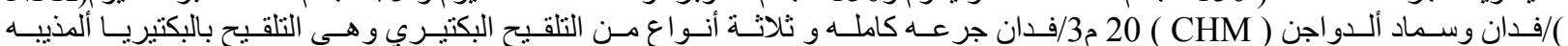

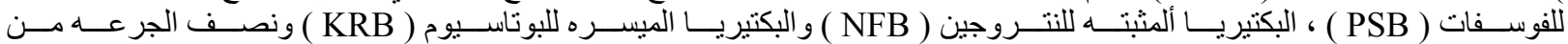

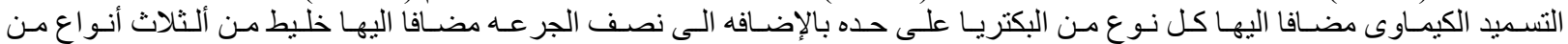

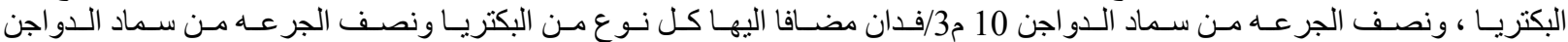

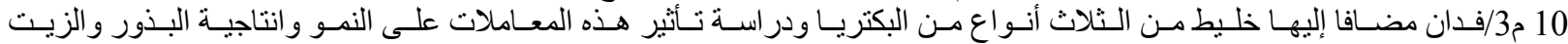
الثابت لنبات الخردل الأبيض Brassica alba. حيث أظهرت النئ النتائج المتحصل عليها:

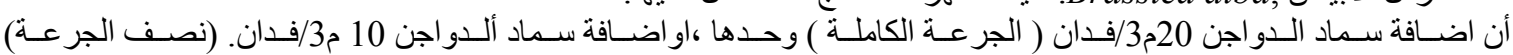

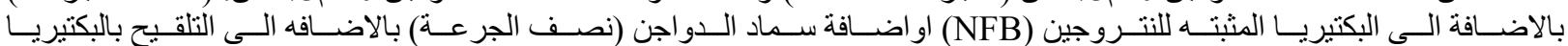

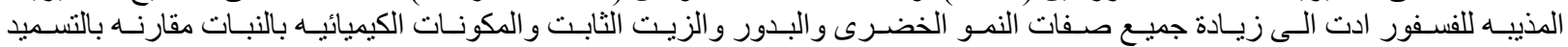

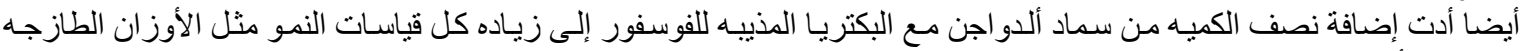

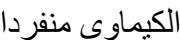

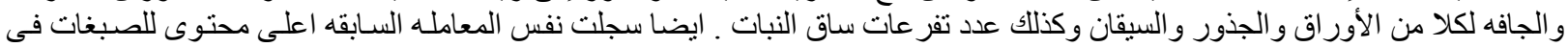

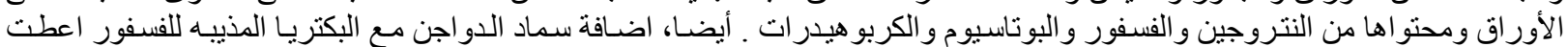

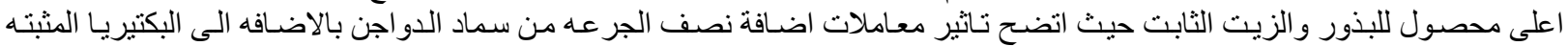

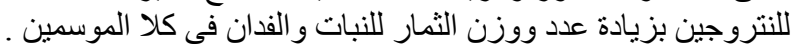

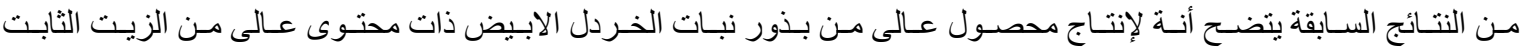

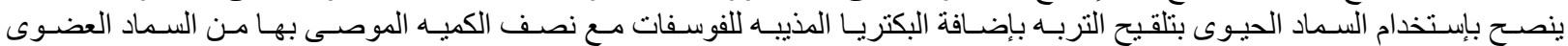

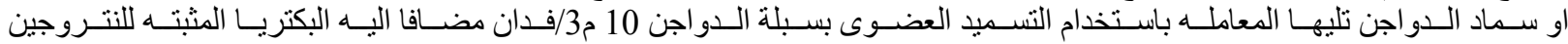
بهدف انتاج نباتات طبيه خاليه من بقايا المو اد الكيميائيه . 